\title{
Determination of Atraton in Irrigation Canal Water and Soil Samples by Gas Chromatography Mass Spectrometry
}

\author{
Gülten Çetin ${ }^{1 *}$ \\ 1* Ylldı Technical University, Faculty of Art and Science, Chemistry Department, 34220, İstanbul, Turkey (ORCID: 0000-0001-7441-1660)
}

(First received 30 April 2021 and in final form 20 September 2021)

(DOI: 10.31590/ejosat.930502)

ATIF/REFERENCE: Çetin, G. (2021). Determination of Atraton in Irrigation Canal Water and Soil Samples by Gas Chromatography Mass Spectrometry. European Journal of Science and Technology, (27), 522-525.

\begin{abstract}
Benefits such as disease prevention, improved food quality and yield are attributed to pesticide usage but severe health effects that arise from their wrong usage and continual accumulation in the environment has called for constant monitoring. This study was performed to determine atraton in irrigation canal water and soil samples by gas chromatography mass spectrometry with high accuracy. Satisfactory analytical figures of merit were obtained for the analyte. Under the optimum conditions, the analyte was not detected in the analysis of irrigation canal water and soil samples and was therefore spiked at different concentrations within the linear calibration range. In order to increase the accuracy of quantifying the analyte in the complex soil matrix, calibration standards were prepared in soil extracts. The percent recoveries calculated for spiked irrigation canal water samples by calibration standards prepared in ultrapure water ranged between $97.6 \pm 2.2 \%$ and $109.6 \pm 0.6 \%$. The percent recoveries calculated for spiked soil samples using the calibration standards prepared ranged between $90.3 \pm 2.3 \%$ and $103.2 \pm 8.2 \%$. The linear dynamic range was obtained in the concentration of $0.25-10 \mathrm{mg} / \mathrm{L}$. The values for LOD, LOQ and \%RSD were respectively $0.08 \mathrm{mg} / \mathrm{L}, 0.26 \mathrm{mg} / \mathrm{L}$ and $8.0 \%$.
\end{abstract}

Keywords: Atraton; Pesticide; GC-MS; Irrigation canal water; Soil.

\section{Atratonun Sulama Kanalı Suyu ve Toprak Örneklerinde Gaz Kromatografisi Kütle Spektrometresi ile Tayini}

$\ddot{O} \mathbf{z}$

Hastalıkların önlenmesi, arttırılmış gıda kalitesi ve ürün verimi gibi faydalar, pestisit kullanımı ile ilişkilendirilmektedir, ancak bunların yanlış kullanımının ve çevrede birikimlerinin sonucunda ortaya çıkan ciddi sağlık etkileri sürekli olarak izlenmelerini gerektirmektedir. Bu çalışma, atratonun sulama kanalı suyu ve toprak örneklerinde gaz kromatografisi- kütle spektrometresi ile yüksek doğrulukta tayinini gerçekleştirmek için yürütülmüştür. Analit için tatmin edici analitik performans verileri elde edilmiştir. Optimum koşullar altında, sulama kanalı suyu ve toprak örneklerinde yapılan analizlerde analit tespit edilememiş ve bu nedenle doğrusal çalışma aralığında bulunan farklı derişimlerde analit standartı ilave edilmesi işlemi gerçekleştirilmiştir. Karmaşık toprak matriksindeki analitin tayininin doğruluğunu arttırabilmek için kalibrasyon çözeltileri toprak örnekleri içerisinde hazırlanmıştır. Standart ilave edilmiş sulama kanalı suyu örnekleri için ultra saf suda hazırlanan kalibrasyon standartlarına göre hesaplanan geri

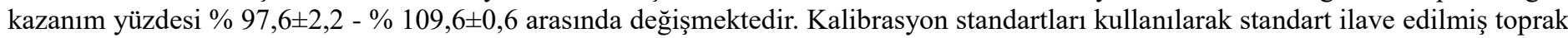
örnekleri için hesaplanan geri kazanım yüzdesi ise $\% 90,3 \pm 2,3-\% 103,2 \pm 8,2$ aralığındadır. Doğrusal dinamik aralık $0,25-10 \mathrm{mg} / \mathrm{L}$ derişiminde elde edildi. LOD, LOQ ve \%RSD sırasıyla; $0,08 \mathrm{mg} / \mathrm{L}, 0,26 \mathrm{mg} / \mathrm{L}$ ve $\% 8,0 \mathrm{dir}$.

Anahtar Kelimeler: Atraton; Pestisit; GC-MS; Sulama kanalı suyu; Toprak.

*Corresponding Author: gultencetin1@hotmail.com 


\section{Introduction}

Pesticides are one of the most economical and effective techniques among the variety of measures used to control, prevent and destroy pests that are a nuisance to humans, plants and animals (Pan et al., 2019). Therefore, the global consumption of natural and synthetic pesticides has increased steadily over the years for application areas including agriculture, parks, homes, gardens, hospitals and other public places (Ramakrishnan, Kadiyala, Sethunathan, \& Mallavarapu, 2019). The desired pesticide is one which can act specifically against the target organism without affecting the host organism (Bolognesi \& Merlo, 2019). A simple pesticide includes dozens of chemicals such as synergist, emulsifiers, surfactants, thickeners, safeners, buffers or defoaming agents used to increase the effectiveness of the pesticide and to extend the pesticide shelf-life or protect them from degradation (Ascherio et al., 2006). Despite the widespread usage and benefits, pesticides can be harmful for unintended organisms when applied wrongly or at dosages higher than the allowable amount. Inappropriate application and exploitation of pesticides may cause any contaminations in air, soil, plant tissues or water sources (Jayaraj, Megha, \& Sreedev, 2016). Since pesticides can be found anywhere in worldwide and it has become a major concern for environmental safety and human health. Exposure to humans can occur through multiple pathways such as consuming contaminated food products, drinking contaminated water or direct inhalation of air polluted with pesticides. The adverse effects that may arise from exposure varies depending on the duration and route of exposure, and the toxicity level of the pesticide (Dhananjayan \& Ravichandran, 2018). Some common health disorders associated with pesticide exposure include allergies, asthma, hypersensitivity, hormone disruption, and cancer (Kim, Kabir, \& Ara Jahan, 2016).

Herbicides are known as a group of pesticides classified according to their target organisms, weeds. These chemicals are extensively preferred due to their water solubility, easy hydrolysis and adsorption properties (Hromadová et al., 2013). Herbicides are used in areas such as industrial sites, irrigation canals, recreational areas, roadsides, lawns, ditch banks, railroad embankments and fence lines (Bolognesi \& Merlo, 2019). The triazine herbicides are chemicals that have symmetrical sixmembered ring with alternating carbon and nitrogen atoms $(\mathrm{Hu}$ $\&$ Chen, 2013). These herbicides are characteristically used to control broadleaf weeds (Báez, Fuentes, \& Espinoza, 2013). Studies have shown that triazene pesticides have the potential to cause severe human health effects including endocrine disruption related diseases, cancers and birth defects (Wang et al., 2015). For this reason, the European Union and the Environmental Protection Agency (EPA) have set $0.05-0.25$ $\mathrm{mg} / \mathrm{kg}$ as maximum residual limit for most products or banned highly toxic pesticides from use (Wang et al., 2015; Xie et al., 2019). Thus, there is the need to monitor environmental samples to ensure these toxic chemicals are not present or within the acceptable limits.

Pesticides are widely determined by using a chromatographic techniques (Stachniuk \& Fornal, 2016). Liquid chromatography (LC) and gas chromatography (GC) are the main types of chromatographic instrumentation that are classified according to the physical state of the mobile phase (Coskun, 2016). GC is very convenient for volatile organic compounds and there are several detection systems. GC can be coupled with including thermal conductivity detector (TCD), nitrogen phosphorus detector (NPD), flame ionization detector (FID), electron capture detector (ECD) and flame photometric detector (PID) (Forgács \& Cserháti, 2003). In addition, GC is combined with mass spectrometry (GC-MS) to achieve a more accurate, selective and precise determination of compounds, as well as characterization of unknown compounds (Niessen, 2017).

The aim of this study was to determine the triazine herbicide atraton by GC-MS in irrigation canal water and soil samples with a simple, but accurate and precise analytical method.

\section{Material and Method}

\subsection{Instrumentation}

Atraton was eluted through a $30 \mathrm{~m}$ non-polar HP-5MS capillary column, having internal diameter and film size values of $250 \mu \mathrm{m}$ and $0.25 \mu \mathrm{m}$, respectively. The column was fixed in the oven of an Agilent 6890 gas chromatograph, connected to an Agilent 5973 mass spectrometer. Atraton was qualified and quantified with the fragment ions $(\mathrm{m} / \mathrm{z}) 58$ and 196, respectively. The ionization energy of the detector was $70 \mathrm{eV}$, and the respective temperatures of the transfer line, MS Quad and MS Source were $280{ }^{\circ} \mathrm{C}, 150{ }^{\circ} \mathrm{C}$ and $230{ }^{\circ} \mathrm{C}$. Ultrapure helium gas $(99.999 \%)$ was used as carrier gas at a constant flow rate of 2.5 $\mathrm{mL} / \mathrm{min}$. The sample inlet temperature was set at $250{ }^{\circ} \mathrm{C}$ and an injection volume of $1.0 \mu \mathrm{L}$ was used for all sample/standard solutions. A simple temperature program of $50{ }^{\circ} \mathrm{C} / \mathrm{min}$ from $80^{\circ} \mathrm{C}$ to $280^{\circ} \mathrm{C}$ was used to elute atraton from the column.

\subsection{Chemicals}

Atraton (CAS\# 1610-17-9) standard was purchased from Dr. Erhrenstorfer (Augsburg - Germany) and a $685 \mathrm{mg} / \mathrm{L}$ standard stock solution prepared in ethanol. Aliquots were taken from the stock solution to prepare calibration standards and intermediate standard solutions for spiking experiments. The ethanol in analytical grade was purchased from Merck (Germany). The microsyringe $(10 \mu \mathrm{L})$ used in the study was washed once with both methanol and ethanol, before and after each sample injection.

\subsection{Samples}

Irrigation canal water was sampled into a $1.0 \mathrm{~L}$ polypropylene bottle by rinsing the bottle several times with the sample and filling to the brim. The water sample was filtered in the laboratory through $125 \mathrm{~mm}$ filter papers before performing analysis. Soil was taken from different points of the university field and homogenized into a bulk sample. The bulk sample was grinded into fine particles and sieved through a $0.10 \mathrm{~cm}$ sieve.

\section{Results and Discussion}

GC-MS system was optimized to lower the detection limit for the analyte. The repeatability of all extractions and instrumental read-out was determined using the average of three integrated peak area values. 


\subsection{Qualitative and quantitative analysis}

Atraton was eluted from the column at 3.36 min using the temperature program specified in section 2.1. The sharp single peak shown in Figure 1 for $50 \mathrm{mg} / \mathrm{L}$ standard solution was confirmed as atraton by extracting its five prominent ion fragments from the total ion chromatogram which resulted in five peaks in the merged format overlaying at the same retention time. The ions of atraton were taken from the search program of the National Institute of Science and Technology (NIST) mass spectrum database. The mass spectrum of atraton also conformed to the in-built compound database of the ChemStation program. A calibration curve was developed with integrated peak areas of standard solutions prepared between 0.25 and $50 \mathrm{mg} / \mathrm{L}$. The linear dynamic range $(0.25-10 \mathrm{mg} / \mathrm{L})$ produced a coefficient of determination value of 0.9997 . The lowest calibration standard $(0.25 \mathrm{mg} / \mathrm{L})$ had a signal to noise ratio greater than 3 and it was measured six times to calculate standard deviation (SD). The expressions given below were used in calculating the limits of detection (LOD), limit of quantification (LOQ) and percent relative standard deviation (\%RSD):

$\begin{array}{ll}\text { LOD: } & 3 \times \text { StdDev/slope } \\ \text { LOQ: } & 10 \times \text { StdDev/slope }\end{array}$

LOQ: $\quad 10 \times$ StdDev/slope

\%RSD: (StdDev/Average) x 100

The respective values calculated for LOD, LOQ and \% RSD were $0.08 \mathrm{mg} / \mathrm{L}, 0.26 \mathrm{mg} / \mathrm{L}$ and $8.0 \%$. The low $\%$ RSD value signified good instrumental repeatability for replicate measurements and the detection limit was in the mid parts per billion level.

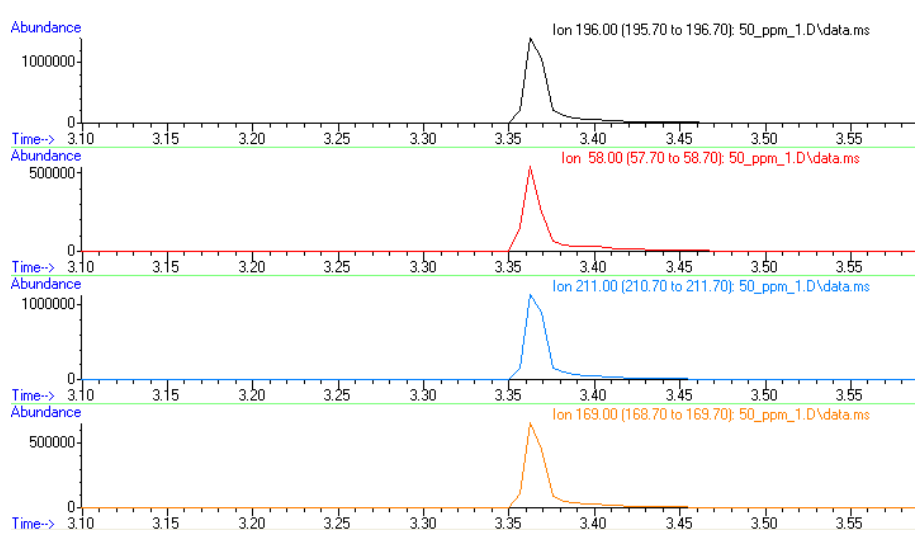

Figure 1. Extract ion chromatogram showing over of atraton ions $\mathrm{m} / \mathrm{z}$ : 196, 58, 211 and 169.

\subsection{Irrigation canal water recovery}

Irrigation canals are constructed on farmlands for a constant supply of water to crops. Application of pesticides could result in their contamination and the level of pesticides could increase over time due to accumulation. Soluble pesticides could migrate in plants when the contaminated water is used for irrigation. There are several other compounds that could contaminate water in irrigation canals and these could affect the accuracy of quantifying an analyte(s) of interest in the sample. Water taken from an irrigation canal was analyzed for atraton content but no signal was observed at the determined retention time. The sample was then spiked at four different concentrations (1.0, 2.5, 5.0 and $10 \mathrm{mg} / \mathrm{L}$ ). When quantified against calibration standards prepared in ethanol, very low percent recovery results $(<70 \%)$ were obtained. Thus, calibration standards were prepared in ultrapure water and the recovery results calculated for 1.0, 2.5, 5.0 and $10 \mathrm{mg} / \mathrm{L}$ were close to $100 \%$ as shown in Table 1 .

\subsection{Soil recovery}

Soils are the secondary recipients of pesticides during application since a great percentage fall directly onto them and eventually drip of the leaves of plants. Pesticides that are insoluble stay for very long periods in the soil and could affect microorganisms or end up in the roots of plants. Soil analysis is therefore very crucial but it has a very complex matrix of several organic and inorganic compounds. Fine soil samples were weighed $(10 \mathrm{~g}$ each) into $15 \mathrm{~mL}$ centrifuge tubes and spiked at 2.5, 5.0 and $10 \mathrm{mg} / \mathrm{L}$ concentrations. Since ethanol was used to dissolve atraton standard, $5.0 \mathrm{~mL}$ was used to extract the spiked soil samples by mechanical shaking for $15 \mathrm{~min}$. After the sample agitation period, the tubes were centrifuged for $120 \mathrm{~s}$ at $600 \mathrm{rpm}$ and filtered clean for instrumental determination. The percent recoveries calculated against calibration standards (in ethanol) were satisfactory as presented in Table 1 . The recovery results calculated for both irrigation canal and soil sample were satisfactory and showed that atraton can be quantified in the two matrices with high accuracy and precision.

Table 1. Percent recoveries for irrigation canal water and soil samples spiked at different concentrations.

$\begin{array}{ccc}\text { Spiked } & \text { Irrigation Canal } * & \text { Soil } * *\end{array}$

$1.0 \mathrm{mg} / \mathrm{L}$

$109.2 \pm 4.2 \%$

$2.5 \mathrm{mg} / \mathrm{L}$

$109.6 \pm 0.6 \%$

$103.2 \pm 8.2 \%$

\section{$5.0 \mathrm{mg} / \mathrm{L}$}

$97.6 \pm 2.2 \%$

$93.0 \pm 1.0 \%$

$10 \mathrm{mg} / \mathrm{L}$

$100.1 \pm 0.7 \%$

$90.3 \pm 2.3 \%$

* represents analyte quantified with aqueous standard solution and ** represents analyte quantified with calibration standards prepared in ethanol.

\section{Conclusions and Recommendations}

In this study, atraton was directly determined in irrigation canal water and soil samples by gas chromatography mass spectrometry. The analyte was eluted from the capillary column using an appropriate temperature program within $4.0 \mathrm{~min}$. The two sample matrices selected for recovery studies are crucial sources for agricultural farmlands and therefore require efficient methods of analysis. Accurate quantification of atraton in irrigation canal water was achieved using aqueous calibration standards. An efficient extraction method was used to obtain almost $100 \%$ recovery of atraton from soil sample spiked at different concentrations. 


\section{References}

Ascherio, A., Chen, H., Weisskopf, M. G., O'Reilly, E., McCullough, M. L., Calle, E. E., Schwarzschild, M.A., \& Thun, M. J. (2006). Pesticide exposure and risk for Parkinson's disease. Annals of Neurology, 60(2), 197203. doi:10.1002/ana.20904

Báez, M. a. E., Fuentes, E., \& Espinoza, J. (2013). Characterization of the atrazine sorption process on andisol and ultisol volcanic ash-derived soils: kinetic parameters and the contribution of humic fractions. Journal of Agricultural and Food Chemistry, 61(26), 6150-6160. doi:10.1021/jf400950d.

Bolognesi, C., \& Merlo, F. D. (2011). Pesticides: Human Health Effects In: Nriagu, J.O., Ed., Encyclopedia of Environmental Health, (pp. 438-453). Elsevier, Burlington.

Coskun, O. (2016). Separation techniques: chromatography. Northern Clinics of Istanbul, 3(2), 156-160.

Dhananjayan, V., \& Ravichandran, B. (2018). Occupational health risk of farmers exposed to pesticides in agricultural activities. Current Opinion in Environmental Science \& Health, 4, 31-37. doi:https://doi.org/10.1016/j.coesh.2018.07.005

Forgács, E., \& Cserháti, T. (2003). CHROMATOGRAPHY | Principles. In: B. Caballero (Ed.), Encyclopedia of Food Sciences and Nutrition (Second Edition), (pp. 1259-1267). Oxford: Academic Press.

Hromadová, M. n., Pospíšil, L. r., Sokolová, R., Bulíčková, J., Hof, M., Fischer-Durand, N., \& Salmain, M. 1. (2013). Atrazine-based self-assembled monolayers and their interaction with anti-atrazine antibody: building of an immunosensor. Langmuir, 29(52), 16084-16092.

Hu, S.-W., \& Chen, S. (2013). Adsorption of triazine derivatives with humic fraction-immobilized silica gel in hexane: A mechanistic consideration. Journal of Agricultural and Food Chemistry, 61(36), 8524-8532.

Jayaraj, R., Megha, P., \& Sreedev, P. (2016). Organochlorine pesticides, their toxic effects on living organisms and their fate in the environment. Interdisciplinary Toxicology, 9(3-4), 90-100. doi:10.1515/intox-20160012

Kim, K.-H., Kabir, E., \& Ara Jahan, S. (2016). Exposure to pesticides and the associated human health effects. Science of The Total Environment, 575, 525-535. doi:10.1016/j.scitotenv.2016.09.009.

Niessen, W. M. A. (2017). Mass Spectrometry: Chromatography-MS, Methods. In: J. C. Lindon, G. E. Tranter, \& D. W. Koppenaal (Eds.), Encyclopedia of Spectroscopy and Spectrometry (Third Edition), (pp. 758-763). Oxford: Academic Press.

Pan, X.-1., Dong, F.-s., Wu, X.-h., Xu, J., Liu, X.-g., \& Zheng, Y.-q. (2019). Progress of the discovery, application, and control technologies of chemical pesticides in China. Journal of Integrative Agriculture, 18(4), 840-853. doi:https://doi.org/10.1016/S2095-3119(18)61929-X

Ramakrishnan, B., Kadiyala, V., Sethunathan, N., \& Mallavarapu, M. (2019). Local applications but global implications: Can pesticides drive microorganisms to develop antimicrobial resistance? Science of The Total Environment, 654, 177-189. https://doi.org/10.1016/j.scitotenv.2018.11.041
Stachniuk, A., \& Fornal, E. (2016). Liquid ChromatographyMass Spectrometry in the Analysis of Pesticide Residues in Food. Food Analytical Methods, 9(6), 1654-1665. doi:10.1007/s12161-015-0342-0

Wang, Y., Sun, Y., Xu, B., Li, X., Wang, X., Zhang, H., \& Song, D. (2015). Matrix solid-phase dispersion coupled with magnetic ionic liquid dispersive liquid-liquid microextraction for the determination of triazine herbicides in oilseeds. Analytica Chimica Acta, 888, 6774. doi:https://doi.org/10.1016/j.aca.2015.07.028

Xie, Y., Wang, M., Chen, X., Wang, S., Han, D., Han, Y., \& Yan, H. (2019). 3-Aminophenol-glyoxylic acid resin for the determination of triazine herbicides in tomatoes. Analytica Chimica Acta, 1061, 122-133. doi:https://doi.org/10.1016/j.aca.2019.01.062 